\title{
Combates pela formação da normalista católica em Patos de Minas (Minas Gerais, Brasil, 1948-1960)
}

\author{
Combats for the formation of Catholic Normal graduate \\ in Patos de Minas (Minas Gerais, Brasil, 1948-1960)
}

Combates por la formación normalista católica en Patos de Minas (Minas Gerais, Brasil, 1948-1960)

AMANDA DE LIMA CARNEIRO IDa

Giseli CRIStina do Vale Gatti (iDb

\section{Resumo}

Trata-se da comunicação de resultados de pesquisa em temática relacionada à formação de normalistas no âmbito de instituições católicas como estratégia de combate da Igreja ao avanço de ideias liberais e das denominações religiosas protestantes, particularmente na cidade de Patos de Minas, no Estado brasileiro de Minas Gerais, no período compreendido entre 1948 e 1960. O objeto privilegiado foi a Escola Normal Nossa Senhora das Graças, por meio da qual objetivou-se apreender parte das estratégias católicas de manutenção de sua relevância em um mundo histórico que se transformava e que se abria a novas formas de compreensão da vida e da sociedade, dentre as quais teve destaque a criação e a manutenção de instituições destinadas à formação de professoras para atuarem na educação escolar primária. Em termos metodológicos, partiu-se do exame da documentação legal existente, dos impressos jornalísticos e de farta iconografia, com importante acréscimo de depoimentos colhidos junto às egressas

\footnotetext{
a Universidade de Uberaba (Uniube), Uberaba, MG, Brasil. Mestre em Educação, e-mail: amanda.Icps@hotmail.com

b Universidade de Uberaba (Uniube), Uberaba, MG, Brasil. Doutora em Educação, e-mail: giseli.vale.gatti@gmail.com
} 
da instituição escolar, no esforço de apreender os aspectos mais relevantes do empreendimento católico. Percebeu-se que ao lado de garantir a formação de um corpo docente católico no ensino primário da cidade, a Escola Normal católica, também colaborou para a perpetuação de uma mentalidade que restringia o papel da mulher na cidade e na sociedade ao de mãe zelosa e esposa fiel.

Palavras-chave: História. Educação. Escola Normal. Igreja Católica. Minas Gerais.

\begin{abstract}
This work regards the communication of research results whose subject is about the formation of Normal School students in the context of Catholic institutions as a strategy of combat from the Church to the advance of liberal ideas and Protestant religious denominations, particularly in the city of Patos de Minas, in the Brazilian State of Minas Gerais, within 1948 to 1960. The privileged object was the Normal School of Our Lady of Grace, through which we sought to learn part of the Catholic strategies to maintain its relevance in a historical world that was under transformation, and opened to new forms of life and society comprehension, where the creation and maintenance of institutions destined to the instruction of female teachers to work at school primary education deserves a special attention. In terms of methodology, we started by examining the existing legal documentation, journalistic impressions, and vast iconography, besides relevant declarations collected next to graduates from this school institution, to apprehend the more significant aspects of the Catholic project. We perceived that besides guaranteeing the formation of Catholic teaching staff in the primary education of the city, the Catholic Normal School also collaborated with the perpetuation of a mentality that restricted the role of women of the city and society of the one of careful mother and loyal wife.
\end{abstract}

Keywords: History. Education. Normal School. Catholic Church. Minas Gerais.

\title{
Resumen
}

Se trata de la comunicación de resultados de una investigación relacionada a la formación de normalistas en el ámbito de instituciones católicas, como estrategia de combate de la Iglesia al avance de ideas liberales y de las denominaciones religiosas protestantes, particularmente en la ciudad de Patos de Minas, en el Estado brasilero de Minas Gerais, en el periodo comprendido entre 1948 y 1960. El objeto privilegiado fue la Escuela Normal Nuestra Señora de las Gracias, por medio de la cual, se buscó entender parte de las estrategias católicas de manutención de su relevancia en un mundo histórico que se transformaba y que se abría a nuevas formas de comprensión de la vida y de la sociedad, dentro de las cuales, se destacó la creación y la manutención de instituciones destinadas a la formación de profesoras para que actuaran en la educación primaria. En términos metodológicos, se dio inicio con el examen de la documentación legal existente, de los impresos periodísticos y una amplia iconografía, con importante aporte de testimonios recolectados con egresadas de la institución escolar, en el esfuerzo de entender los aspectos más relevantes del emprendimiento católico. Se percibió que al lado de garantizar la 
formación en un cuerpo docente católico en la enseñanza primaria de la ciudad, la Escuela Normal católica, también colaboró para la perpetuación de una mentalidad que restringía el papel de la mujer en la ciudad y en la sociedad al de madre celosa y esposa fiel.

Palabras clave: Historia. Educación. Escuela Normal. Iglesia Católica. Minas Gerais.

\section{Introdução}

Apesar de a república brasileira datar de 1889, as dificuldades de construção de uma sociedade liberal, tal como preconizada no melhor do ideário de referência republicano ainda constituem uma problemática visível no Brasil atual, no qual avanços civilizatórios importantes convivem com problemas básicos de saneamento, atendimento à saúde e qualidade da formação escolar. Não é diferente a situação da mulher, que apesar de avanços na escolarização e na ocupação de trabalho remunerado, convive com toda sorte de dificuldades, do feminicídio, da dupla jornada e da remuneração menor.

No seio desse universo contraditório é que procuramos dimensionar a forma como se travaram verdadeiros combates em torno da formação de normalistas ao longo do século XX, nos quais as diferentes instâncias promotoras do ensino nomeadamente, estatais, confessionais e da sociedade civil — buscaram assegurar sua relevância nas diferentes cidades brasileiras e, portanto, no país, no intuito de ter presente nas escolas primárias um corpo docente aguerrido na defesa de um ideário de referência obtido nas escolas normais, nas quais se prepararam para o exercício profissional, em uma época na qual se buscava garantir maior qualidade à educação primária nacional em meio a um enorme crescimento demográfico, que dificultava a implementação de qualquer política pública, seja puramente estatal ou mesmo em cooperação com a iniciativa particular.

Nesse propósito geral, buscamos avançar no entendimento da relação entre uma mentalidade nacional marcada pela ideia de uma ordem patriarcal familiar, notadamente reproduzida pelo Estado e pelo conjunto das religiões, em especial, pela católica, diante do qual o mundo feminino era silenciado nas diferentes esferas da vida social, sendo a mulher, desde menina, educada para o lar — para ser mãe e esposa. 
Assim, a educação da mulher não focava sua participação na vida urbana que se adensava no período, o que tinha consequências, sobretudo, em um estado como o de Minas Gerais, no qual a urbanização se acelerou ano após ano. Nesse sentido, a livre circulação em locais públicos de mulheres pertencentes às famílias remediadas e de alto poder aquisitivo era restrita a algumas ocasiões especiais, tais como nas missas e nas procissões religiosas, o que se ajustava melhor a um mundo histórico do passado, antes dos importantes processos levados a termo de autonomia feminina.

Desse modo, no intuito de compreender a importância da educação feminina, atentou-se para o estudo das instituições escolares, especificamente o Colégio Nossa Senhora das Graças, por ser uma das mais antigas da cidade de Patos de Minas (MG). Dada a importância dos estudos voltados para a história das instituições escolares, procuramos adentrar em leituras sobre a questão, principalmente, no intuito de compreender os processos educacionais e formativos no interior de uma escola confessional católica feminina.

Em termos metodológicos optou-se por dois conjuntos de fontes que não se excluem, pelo contrário, complementam-se: as fontes documentais e a história oral. Nesta pesquisa a história oral foi um importante instrumento, uma vez que nos arquivos da escola, tivemos acesso a dados importantes de ex-alunas que permitiram o contato com quatro delas no intuito de enriquecer as informações que tínhamos a partir da documentação.

Ao elaborar o roteiro das entrevistas foram levados em conta os objetivos propostos, sobretudo, na direção de apreender parte das estratégias católicas de manutenção de sua relevância em um mundo histórico que se transformava e que se abria a novas formas de compreensão da vida e da sociedade, dentre as quais teve destaque a criação e a manutenção de instituições destinadas à formação de professoras para atuarem na educação escolar primária.

Para compor o corpus documental foi fundamental a busca de fontes tais como jornais, livros de atas de reuniões, registros de alunas, de notas, de disciplinas, entre outros, além de fontes iconográficas encontradas no acervo da própria escola. Nessa direção, cabe destacar o livro Mosaico, escrito no ano de 2015, pela Irmã Marina Guilhermina de Oliveira (2015) em comemoração ao aniversário de 70 anos do Colégio Nossa Senhora das Graças. Em termos de referencial teórico, buscou-se, 
principalmente nas contribuições de Azzi (1981), Fernandes (2017), Fonseca (1974), Mello (1978), Oliveira (2015), Resende (2006) e Vieira (2000).

O artigo está estruturado em três partes. Na primeira há o entendimento da maneira pela qual se constitui a cidade de Patos de Minas. Em seguida, uma incursão sobre as formas pela qual se deu a escolarização nessa cidade. Por fim, o esforço de aprender os processos de formação de normalistas católica na Escola Normal Nossa Senhora das Graças.

\section{A constituição do município de Patos de Minas}

O município de Patos de Minas está situado no estado de Minas Gerais, na mesorregião denominada Triângulo Mineiro e Alto Paranaíba, sendo constituído de sete distritos: Patos de Minas, Bom Sucesso de Patos, Chumbo, Major Porto, Pilar, Pindaíbas e Santana de Patos. Inicialmente conhecida como Lagoa dos Patos, a cidade de Patos de Minas surgiu na segunda década do Século XIX, onde se fixaram seus primeiros moradores, lavradores e criadores de gado, a saber: "Em 1820 se iniciara o agrupamento de casas que viria a ser a cidade de Patos de Minas" (MELLO, 1978, p. 24).

A nomenclatura Lagoa dos Patos deu-se devido à quantidade de patos silvestres que existiam em torno da referida lagoa. A primeira fazenda instalada no local, denominada "Os Patos", já predizia o nome da futura cidade. Em 1828 o arraial de Lagoa dos Patos passou a se chamar Santo Antônio da Beira do Rio Paranaíba, pois já era considerado povoado. Em 1832, alcançando a condição de distrito, teve seu nome alterado para Santo Antônio dos Patos da Beira do Rio Paranaíba que em 1842 foi incorporado ao município de Patrocínio. Posteriormente, em 30 de outubro de 1866, houve emancipação e criação do município de Santo Antônio dos Patos, cuja instalação deu-se em 29 de fevereiro de 1868. No caso, a sede do município passou ao status de Vila, conforme os direitos legais da época.

O pequeno povoado cresceu, virou arraial e depois vila, tendo sido elevada à categoria de cidade no dia 24 de maio do ano 1892, com a denominação de Patos. Por 
essa razão, atualmente, seu aniversário é comemorado em 24 de maio, quando se realiza a Festa Nacional do Milho em comemoração à farta colheita desse grão.

Em 1944 o Governo do Estado de Minas Gerais mudou o nome da cidade para Guaratinga, provocando insatisfação na população. Entretanto, atendendo aos apelos populares, em 3 de junho de 1945 o município é finalmente denominado de Patos de Minas, para distingui-lo de Patos, cidade mais antiga, localizado no estado da Paraíba.

O desenvolvimento mais intenso do município aconteceu na década de 1930, por meio dos melhoramentos executados pelo governo do estado, cujo presidente era o patense Olegário Dias Maciel. Em seu governo instalou-se e construiu-se a sede da Escola Normal (hoje denominada Escola Estadual Professor Antônio Dias Maciel), o Hospital Regional Antônio Dias Maciel e o Fórum Olympio Borges.

No que tange ao desenvolvimento de um sistema educacional, que resultou na criação do Grupo Escolar de Patos, Escola Normal e demais instituições escolares, essa deu-se primeiramente por meio do Decreto n. 4.065, de 23 de dezembro de 1913 (MINAS GERAIS, 1913), que estabeleceu a criação de um grupo escolar na cidade, sendo inaugurado em 4 de junho de 1917. Tratava-se do Grupo Escolar de Patos, que iniciou suas atividades com 321 alunos matriculados, sendo esse número composto pelo público feminino e masculino.

Mais tarde, no ano de 1930, o estabelecimento de ensino passou a ser denominado Grupo Escolar Marcolino de Barros, em homenagem ao político Marcolino de Barros da cidade de Patos de Minas. De acordo com Mello (1978, p. 58), naquela época, criar um Grupo Escolar era tão importante quanto fundar uma faculdade nos dias de hoje. Durante a década de 1930, mais precisamente em 1932, houve a criação da Escola Normal Oficial de Patos de Minas para formar professores primários.

\section{O processo de escolarização em Patos de Minas}

Inicialmente, em Patos de Minas, o ensino foi conduzido por meio do mestreescola. Com a escassez de escolas oficiais instaladas na cidade e mesmo na região, essas figuras eram, em muitos casos, a base da educação urbana e, principalmente, nas 
áreas rurais brasileiras. Foram eles os primeiros educadores rurais, pois ensinavam a ler, a escrever e a fazer contas e, às vezes, utilizavam livros e manuscritos que serviam como instrumentos para auxiliar na alfabetização e, depois, usados nos processos de avaliação do aprendizado.

O mestre-escola poderia ser remunerado parcialmente ou totalmente pelos seus serviços por meio de alimentos produzidos na fazenda, tais como farinha, toucinho, feijão, arroz, ou até mesmo outros instrumentos que se constituíam produtos para a barganha. Ainda em consonância com Fonseca (1974), devido ao grande atraso nos estabelecimentos de escolas rurais, a melhor alternativa era de fato a adoção dos mestres-escolas nessas localidades. Em Patos de Minas não foi diferente, os mestre-escola espalhados por todo o município tiveram um trabalho notório, uma vez que as escolas públicas não eram suficientes para atender à população rural em idade escolar. Importante, portanto, ressaltar que os mestres-escolas foram responsáveis pelo único sistema educacional existente no meio rural de Patos de Minas durante décadas. Mesmo com instalações precárias para a prática da alfabetização e a falta de material adequado, eles possibilitaram que as crianças do meio rural não ficassem completamente alheias ao conhecimento e à educação.

Por volta da metade do século XX os mestres-escolas começaram a perder sua notoriedade, pois as edificações de prédios escolares municipais começaram a aparecer. Nessa época a população do campo passou a ter o ensino institucionalizado e pago pelo poder público e, desse modo, não mais se justificaria a presença do mestre-escola no campo. Além disso, o êxodo rural já começava a esvaziar o campo, sobretudo com migração de grande parte das famílias de maior poder aquisitivo das áreas rurais para o meio urbano, geralmente, em busca de uma educação com melhor qualidade para seus filhos que, na maioria dos casos, só era encontrada nas cidades.

Mello (1978) ressalta que no dia 7 de maio de 1853 foi criada a cadeira de instrução primária do primeiro grau no Arraial de Santo Antônio dos Patos, sendo a primeira escola pública na região. Nos fins da monarquia funcionou uma escola particular dirigida pela inglesa D. Eliza Smith. Na primeira década do Século XX, na cidade, funcionavam as escolas primárias regidas pelos professores Modesto de Melo 
Ribeiro, Felipe Rodrigues Correia e D. Isabel Alves Moreira Sobrinha. Também funcionava a escola primária particular regida por um casal de professores.

Apesar da criação e implantação das referidas escolas no município desde a emancipação em 1866, até a década de 1940, as escolas com ensino oficial não eram suficientes para atender a população em idade escolar. Entre os anos de 1906 e 1929 o município de Patos de Minas contava com alguns educandários. Em 1906 foi criado o Atheneu dedicado ao ensino de matérias do curso ginasial. Em seu corpo docente estavam os senhores Eufrásio José Rodrigues (Aritmética), Marcolino de Barros (Geografia), Paulo Romero (Francês), Sabino Lustosa (Latim) e o Padre Manuel de Macedo (Português). O Atheneu funcionou apenas por quatro anos e não há registros das motivações para seu fechamento.

Em 1910, ainda em consonância com Mello (1971), o Dr. Jaques Dias Maciel fundou outro educandário de grau médio, que embora não tenha sido localizado o período de funcionamento desse estabelecimento, soube-se que também teve vida efêmera e se transformou na escola chamada Aprendizado Agrícola de Patos, instalada na Fazenda Limoeiro. Posteriormente surgiu a ideia de construir um Grupo Escolar, pois apenas as cidades mais avançadas possuíam esse tipo de estabelecimento. De acordo com Mello (1971, p. 193),

O Govêrno do Estado não construía o prédio: competia à população edificá-lo. Para conseguir tal melhoramento, o Dr. Laudelino Gomes de Almeida levantou a estatística da população infantil em idade escolar e entregou ao Secretário do Interior o resultado de seu trabalho. E, imediatamente, na cidade, constituiu-se uma comissão para angariar fundos, estando à frente da mesma o Dr. Laudelino Gomes de Almeida, o Prof. Modesto de Melo Ribeiro e o Cel. Farnese Dias Maciel, que era presidente. Encontrou o melhor acolhimento por parte do povo, e todos deram o seu auxílio para que se erguesse em Patos o majestoso prédio do Grupo Escolar. Na primeira lista de subscrição conseguiram a significativa quantia de 5:900\$000. Olegário Maciel, então Deputado à Assembléia Legislativa, conseguiu que o Govêrno do Estado contribuísse com um terço e a Câmara Municipal com o terço restante. Era presidente da Câmara o Agente Executivo equivalente a Prefeito - o Dr. Marcolino Ferreira de Barros. Organizada a planta do prédio e obtidos os fundos, houve a escolha do local. As opiniões divergiram, mas venceu a de se adquirir a Casa da Mata, comprido aglomerado de casas de pouco valor, existente na atual praça D. Eduardo, onde hoje está o Colégio Nossa Senhora das Graças. Em 1913 foi iniciada a construção, terminada em 1915. Restava a instalação, para o que, o Gôverno exigia professorado devidamente habilitado. Buscou-se, em Patrocínio, o Prof. Modesto de Melo Ribeiro, que lá dirigia o grupo recém-instalado. Depois de quase dois anos de espera e lutas, foi finalmente formado o corpo docente, feitas as matriculas de 187 crianças de ambos os sexos e, finalmente, em 4 de junho de 1917, instalado solenemente o Grupo Escolar Marcolino de Barros, nome dado pelo voto unânime da população em 
homenagem ao cidadão emérito que muito trabalhara para a concretização daquele anelo da cidade.

A implantação desse estabelecimento de ensino primário foi um importante acontecimento no processo de escolarização em Patos de Minas. Inicialmente o Grupo Escolar funcionou no prédio construído com recursos da população - o mesmo que em 1940 foi concedido para a instalação do Ginásio Municipal de Patos. No ano de 1943 Olegário Maciel concedeu um novo e definitivo prédio com arquitetura moderna e imponente em comparação com outras construções da cidade.

Em setembro de 1921 tinha-se notícia da possibilidade de fundação de um colégio feminino na cidade, que seria conduzido por freiras do Sagrado Coração de Maria, todavia, isso não ocorreu. Em 1929 é fundado o Instituto Santa Terezinha, pelo Prof. Eduardo Lopes, que havia acabado de chegar à cidade. Ele funcionou por pouco tempo, mantendo somente o curso primário. O cunhado desse professor fundou, anexo ao Instituto, o Colégio Regina, que possuía curso ginasial, mas que também perdurou pouquíssimo tempo.

No mesmo ano Dr. Antônio Dias Maciel fundou o Instituto Sul-Americano que "serviu de núcleo formador da Escola Normal, estabelecimento oficial, e pioneiro do ensino médio da cidade" (MELLO, 1971, p. 194). No que tange à criação da Escola Estadual Professor Antônio Dias Maciel é importante ressaltar que ela foi criada em 1932 pelo então governador da província de Minas Gerais, Olegário Dias Maciel, nomeada de Escola Normal Oficial de Patos de Minas e atualmente denominada Escola Estadual Professor Antônio Dias Maciel, popularmente conhecida na cidade como "Escola Normal", como se comprova o noticiário de um jornal da cidade:

Comemorando no dia 5 de maio do corrente ano [1932], a fundação da Escola Normal desta cidade, os corpos docentes e discentes deste estabelecimento de ensino organizaram naquele dia condignos festejos que tiveram o costumado brilho de sempre, como acontece com todas as comemorações que ali se encerram. O programa constou de um auditório presidido pela aluna Antonia Gomes, [...]. Discorreu sobre a data da senhorinha Maria da Conceição Melo, aluna do $3^{\circ}$ ano normal, que sintetizou com rara felicidade o que foi, o que é e o que será no futuro de Patos a Escola Normal, não se esquecendo, como era natural, de proferir palavras de homenagem ao Dr. Antonio Dias Maciel, o pioneiro da fundação da escola e sua consequente transformação em educandário oficial, com um dos mais suntuosos prédios do Estado (FOLHA DE PATOS, 1937, p. 2). 
A partir de 1935 a Escola Normal Professor Antônio Dias Maciel entregava à sociedade as primeiras normalistas formadas para atuar no ensino das crianças, atendendo às necessidades das escolas municipais rurais de Patos de Minas. A instituição contava em seu quadro discente com alunas de dois segmentos da sociedade: a elite agropecuária e a emergente classe média formada por comerciantes e profissionais de vários setores da economia local. Para captação de alunas havia a divulgação das vagas e, consequentemente, exames para admissão. Em relação a isso a Folha de Patos publica o seguinte:

\begin{abstract}
Escola Normal Oficial de Patos
A secretaria da Escola acha-se aberta, diariamente, das 12 às 15 horas para atender aos interessados que pretendem freqüentar quaisquer dos cursos do estabelecimento. Do dia 1 ao dia 15 de fevereiro: inscrição dos candidatos ao exame de admissão ao curso de adaptação, exame de Segunda época. Do dia 16 ao dia 28 de fevereiro: matrícula nos cursos normal, adaptação e classes anexas. Patos, 30 de janeiro de 1937. Maria Rezende Maciel - Diretora (FOLHA DE PATOS, 1937, p. 3).
\end{abstract}

Com relação aos docentes, eles eram recrutados na própria cidade. Eram homens e mulheres que exerciam as mais variadas profissões, a saber: Antônio Dias Maciel e Ernani de Moraes Lemos eram advogados e exerceram os cargos de diretor da escola e professor de Português e Francês; Maria Rezende Maciel e José de Santana Sobrinho eram farmacêuticos, mas se tornaram professores de Aritmética e de Ciências, respectivamente. Apenas Hilda Maciel, que lecionava Geografia e História, e Maria Madalena Prieto, professora de Português e Francês, tinham formação pedagógica. Além de professores sem a formação específica para suas áreas de atuação, foi observado que não havia docentes aptos para ministrarem disciplinas como Metodologia do Ensino e Psicologia. Isso, de certa forma, comprometia a formação de professores no município e região.

Apesar disso, a Escola Normal fomentava a vida cultural da cidade de modo bastante intenso, por meio de apresentações teatrais, declamação de poemas e leitura de textos literários. A Escola Normal tornava-se lugar das festividades de final de ano quando era aberta ao público para uma apresentação anual. Compareciam autoridades civis, eclesiásticas, militares, pais e professores da Escola Normal. A escola, dessa maneira, tinha uma representação importante na cidade. Nessa direção, a imponência 
da edificação da escola era contrastante com o pequeno número de alunos e a escassez de professores com qualificação específica.

Figura 1 - Fachada da Escola Estadual Professor Antônio Dias Maciel

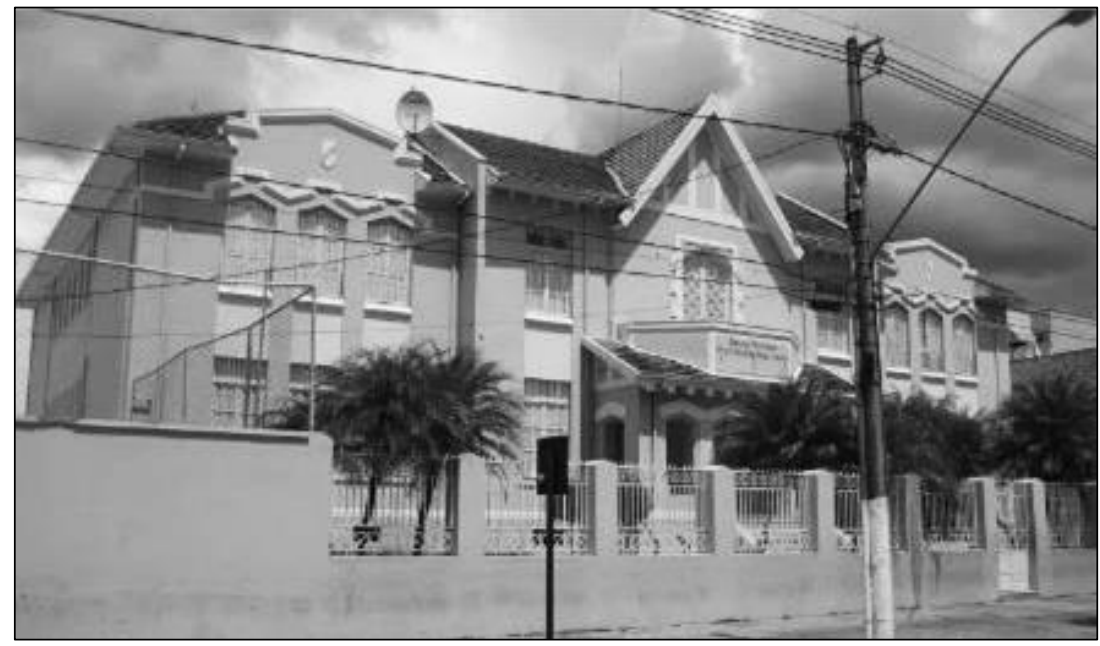

Fonte: Clube Notícia ([20-?]).

Em frente à escola, fundada em 1932, existe até hoje um busto de Olegário Maciel, falecido em 05 de setembro de 1933, que foi instalado em 30 de julho de 1936. Além de a escola ter sido implantada em frente à residência do então presidente da província, Olegário Maciel, ainda teve como primeiro diretor Antônio Dias Maciel (pai de Olegário), atualmente, o patrono da instituição. É importante salientar que os "Macieis", em boa parte, eram presbiterianos. Isso justifica o fato de muitos professores que lecionaram nessa instituição também o serem.

Sem dúvida, esse fato fez com que a Igreja Católica ficasse instigada a tentar fundar uma escola de cunho confessional católico, pois a influência protestante em muitas partes do Brasil, inclusive em Patos de Minas, provocava uma mobilização nesse sentido, ou seja, para conter essa influência e o crescimento aparente do protestantismo.

Assim, a Igreja Católica tentou a posse do novo prédio do Grupo Escolar de Patos (atual escola Marcolino de Barros) junto ao estado, mas isso não se efetivou. Para fazer frente a uma escola de caráter presbiteriano, a localização do Grupo Escolar de Patos se mostrava propícia, uma vez que estava estabelecido à pouca distância da Escola Normal. Com a frustração do primeiro intento, pensou-se então no antigo prédio onde funcionou o Grupo Escolar, pois também estava próximo da escola 
administrada pelos "Macieis" e em frente à capela sagrada Santo Antônio de Pádua, exatamente onde se situa, há 70 anos, o atual Colégio Nossa Senhora das Graças, objeto deste estudo. Novamente o pedido foi negado. Entretanto em 1939 fundou-se, no antigo prédio concedido pelo governo do estado à cúria diocesana, o Ginásio Municipal Benedito Valadares, pelo Dr. Anair de Sant'Ana que, em 1942, passara a direção a Monsenhor Manoel Fleury Curado. De acordo com Mello (1971, p. 195),

Surgiu, em 1939, o segundo estabelecimento de ensino secundário em Patos de Minas sob a designação de Ginásio Municipal de Patos, e posteriormente Ginásio Benedito Valadares, autorizado a funcionar oficialmente em 1940. Nasceu do zêlo apostólico do Mons. Manuel Fleury Curado, vigário da paróquia de Santo Antônio, que auxiliou e encorajou o Dr. Anair Santana, franqueando-Ihe o antigo prédio do Grupo Escolar Marcolino de Barros, verbalmente, para os mesmos fins, concedido pelo Gôverno do Estado à Mitra Diocesana. Em 1942, o Pe. João Batista Balke colaborou como auxiliar do Dr. Anair José de Santana. Em 1943 o Dr. Anair vendeu o ginásio para a Paróquia, que passou para os Padres Sacramentinos de Nossa Senhora, ficando como diretor o Pe. José Batista de Lima.

Em 1943 a direção do Ginásio foi repassada aos Missionários Sacramentinos de Nossa Senhora, ordem religiosa fundada pelo Padre Júlio Maria de Lombaerde, figura fundamental na luta contra o protestantismo ${ }^{1}$. Ele classificava o protestantismo de "o tinteiro do Satanás" e “o destrutor da união". Assim, percebe-se a razão da escolha de uma ordem religiosa por ele fundada para assumir a educação no colégio, pois, acolhe, por certo, os interesses eclesiásticos locais.

Desse modo, em 21 de fevereiro 1945 chegam a Patos de Minas as Irmãs Sacramentinas que deveriam auxiliar os padres da mesma ordem, inclusive, fundando um pensionato para meninas. Logo depois, em 1947, foi criado o Curso Normal. De acordo com o fragmento que segue,

Patos de Minas constituía mais uma etapa da expansão sacramentina em direção ao Oeste. Situa-se na região denominada Mata da Corda, na qual estavam incluídas as cidades de São Gotardo e Carmo do Paranaíba, onde as irmãs já se haviam estabelecido anteriormente. Era mais uma localidade que surgia na área influência da devoção a Nossa Senhora da Abadia (AZZI, 1981, p. 344).

\footnotetext{
${ }^{1}$ Ver a esse respeito: Lombaerde (1950). 
De acordo com Vieira (2000), o ensino permaneceu misto de 1945 a 1948, entretanto, como o número de alunos matriculados diminuía, em 1948 os padres deixaram em definitivo a instituição, sendo que as irmãs assumiram a direção da escola, suprimindo o setor masculino e dedicando-se exclusivamente à educação feminina. A partir disso altera-se o nome para Escola Normal e Ginásio Nossa Senhora das Graças, com a continuidade da educação ministrada em regime de internato e externato. No Art. $1^{\circ}$ do Estatuto da instituição escolar nota-se, claramente, seu objetivo religioso:

Art. $1^{\circ}$ - Denominação e finalidades: A Escola Normal e Ginásio Nossa Senhora das Graças, que é um estabelecimento dirigido pelo Instituto das Irmãs Sacramentinas, mantendo os cursos elementar e secundário, fundado a $1^{\circ}$ de Março de 1940, destina-se a formação integral da infância e da juventude femininas, tem em vista principalmente 0 aperfeiçoamento moral. (ESTATUTO DA ESCOLA, 1952, p. 13).

É interessante perceber que apesar das Irmãs terem vindo para Patos apenas em 1945, desde 1929 o pedido já havia sido feito por monsenhor Fleury para que elas assumissem a catequese e a formação das moças. A sociedade local e regional acreditava que a educação em uma escola dirigida por freiras seria melhor para suas filhas, tendo em vista que o internato era tido como uma opção propícia, naquela época, para muitas famílias. Consequentemente as futuras estudantes deveriam se comportar de acordo com as rígidas normas disciplinares e doutrinárias impostas pela instituição, atendendo aos anseios das lideranças religiosas católicas da cidade. No ano de 1951 iniciou-se a construção do que viria a ser a sede própria da instituição no terreno doado pela Paróquia. 
Figura 2 - Fachada do Colégio Nossa Senhora das Graças

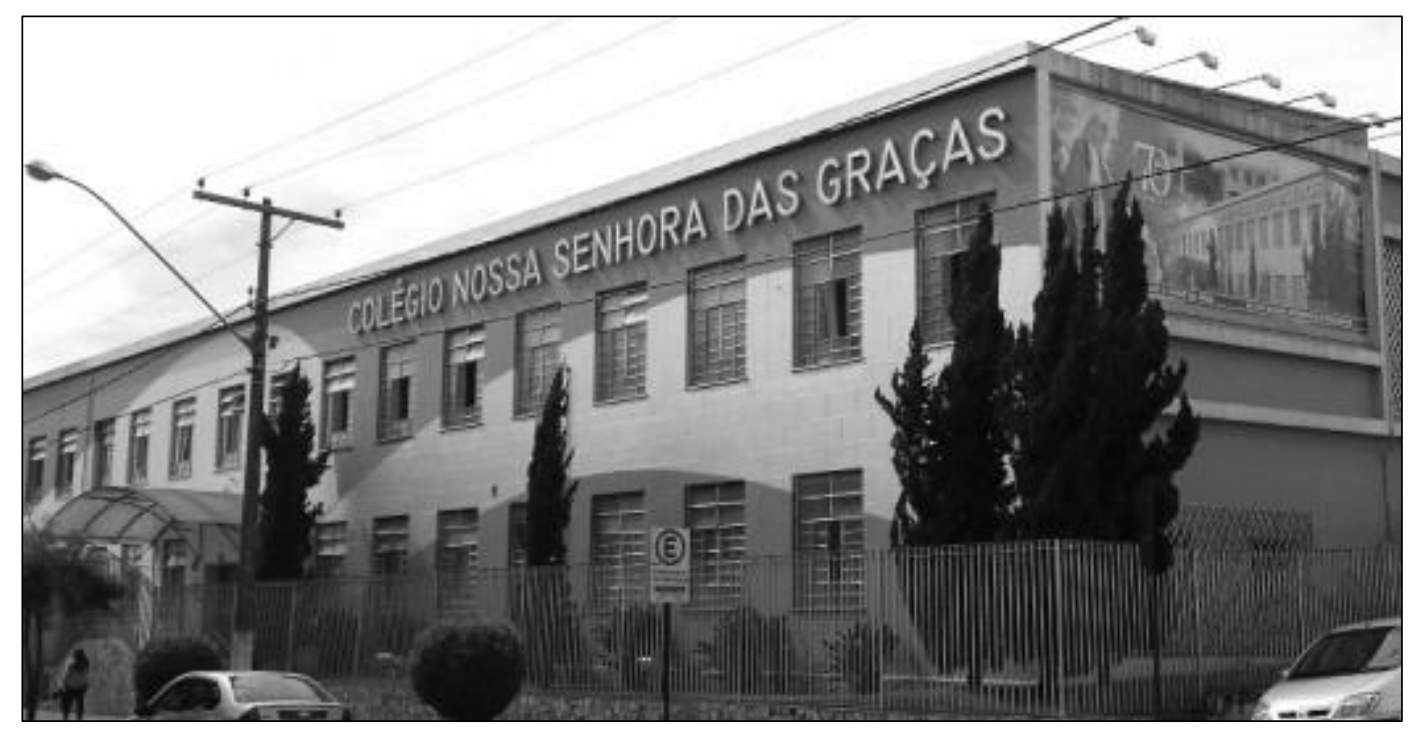

Fonte: Blog Caminhos do Saber (2015).

A construção do edifício levou nove anos, sendo que foi necessário que a sociedade contribuísse com donativos para a efetivação das obras, na direção de que a edificação ficasse apropriado ao atendimento das alunas.

\section{Educação feminina católica na Escola Normal N. S. das Graças}

No propósito de compreender os processos de educação feminina colocados em ação buscamos acessar fontes diversas na própria escola, na imprensa local, mas, também, por meio da coleta de depoimentos de ex-alunas internas que nos concederam entrevistas. Nesse ínterim pudemos perceber que a memória é um pilar da existência humana, desde o nascimento até a morte. A partir dela nós conseguimos conservar vivências e recordar lembranças de momentos da vida quando necessário. Ela guarda do presente o que podemos lembrar no futuro, resgata fragmentos do passado, trazendo de volta vivências e experiências que constituem a vida do 
indivíduo. E para a consolidação deste trabalho a memória das entrevistadas nos permitiu conhecer melhor esse espaço escolar e sua dinâmica de funcionamento.

Formar professores capacitados por meio das Escolas Normais era muito importante. No entanto, como os investimentos do estado não eram suficientes, várias congregações católicas abriram colégios para a formação de normalistas. Além disso, interessava a Igreja ocupar esse espaço como estratégia de manutenção de sua relevância.

Em seu currículo, a Escola Normal Nossa Senhora das Graças oferecia matérias tais como: Português e Literatura, Higiene e Educação Sanitária e Puericultura, História e Filosofia da Educação, Sociologia Educacional, Psicologia Educacional, Metodologia do Ensino Primário, Prática de Ensino, Desenho e Artes Aplicadas, Música e Canto, Educação Física, Biologia Educacional, Matemática, Física e Química, Anatomia e Fisiologia Humanas, Latim, Francês, Inglês, Ciências Naturais, História do Brasil, Geografia do Brasil, História geral, Geografia Geral, Economia Doméstica, Desenho, Trabalhos Manuais e Canto Orfeônico. Além disso, de acordo com a depoente "Nara"?:

[...] o colégio naquele tempo tinha Língua Portuguesa, Língua Latina, Língua Francesa, Língua Inglesa, História Geografia, Biologia, Educação. Física, Ensino Religioso Que Se Chamava Religião Mesmo, Educação Artística, que eram os bordados. Eu aprendi a bordar foi lá, não tive outra oportunidade e também o colégio foi muito rico, pois além de ter as disciplinas que eu falei, a gente tinha higiene e puericultura, era estudar a parte de cuidar de crianças a higiene pessoal, e a gente tinha nota pra tudo isso, música aprendi música que na minha prova final cantei o hino nacional brasileiro. Era matéria, valia nota. A indicação do meu pai pra estudar lá me trouxe muitos benefícios, porque aprendi a ser mais determinada e mais independente, porque lá, as irmãs cuidavam da vigilância, dos aspectos sociais porque a gente tinha aula de civilização de como aprontar uma mesa, como servir um café, como servir um jantar, tudo isso a gente aprendia que se chamava aula de socialização. Tudo assim, representado. Uma coisa muito marcante que a gente tinha no Colégio era os horários de banho, aula de manhã, estudo até a hora do café e depois do café era os horários de banho. Cada uma tinha seu horário e não podia gastar mais de cinco minutos para tomar banho, vestir-se e engraxar os sapatos. Tudo cronometrado (Depoimento concedido em 2017).

Ainda sobre os saberes disseminados, é importante destacar que três pontos embasaram a pedagogia das escolas religiosas: a fé, a moral e o sentido comunitário para que a aluna aprendesse os bons costumes, tornando-a sensível para a vida em

\footnotetext{
${ }^{2}$ Foram utilizados neste texto nomes fictícios para manter o sigilo das entrevistadas.
} 
comunidade, temente a Deus e preocupado com seus semelhantes. De acordo com "Margarida", a influência moral católica contida na proposta educacional da Escola Normal coadunava e mesmo reforçava sua formação religiosa anterior, pois que os princípios e valores ensinados e valorizados na Escola Normal já faziam parte da educação recebida em casa, conforme excerto de seu depoimento exposto abaixo:

Olha, minha família é uma família que reza mais do que come. Tudo era pecado e tudo tinha que fazer, então a vida de lá do colégio não teve nada que influenciasse para que eu mudasse o modo dentro da Igreja, não. Eu tenho uma fé muito grande em Deus e em Nossa Senhora e não consegui adaptar a minha criação ao modo diferente de educar menino hoje (Depoimento concedido em 2017).

As egressas da Escola Normal entrevistadas foram unânimes em afirmar que a rígida disciplina foi a lembrança mais marcante daquela época. As freiras eram muito rigorosas, mas a presença de uma educação completa, com ensinamentos válidos dentro da sala de aula e principalmente em seus lares na educação de suas famílias, também marcaram profundamente suas vidas. A depoente "Clara” afirma que,

O que mais marcava a gente era a disciplina e o cumprimento rígido dos horários. Tudo era muito organizado, com muita rigidez e muita disciplina! A gente acordava as cinco e pouco da manhã. Batiam a campainha lá do dormitório e a gente se levantava. Tínhamos minutos marcados para arrumar a cama em silêncio, que tinha até um prêmio quem arrumasse a cama mais bem arrumada e em menos tempo. A gente ia para o banheiro também tudo com minutos marcados. Eram muitas para poucos banheiros. Depois a gente penteava o cabelo, não podia usar pintura nenhuma. Só penteava e escovava, só. E imediatamente a gente atravessava um corredor que lembro até hoje. Atravessava um corredor e ia direto para a Capela participar da Santa Missa e comunhão, em jejum. E depois descia da Missa e ia direto pro salão do café. [...]. Tudo que ia se iniciar tinha oração, sabe. Toda atividade tinha oração inicial, quando a gente se levantava, a gente rezava. Não conversava, não podia conversar não. [...]. Depois do café a gente já ia para sala de aula com o uniforme azul e branco. Assistia aula normalmente, junto com as externas, igualzinho, não tinha diferença. E depois da aula a gente já ia, já trocava esse uniforme e vestia um comum que era usado diariamente que chamava riscadinho. Ele era riscado de azul e branco, todas iguais também às internas. E a gente ia para o almoço, almoçava e durante o almoço a gente conversava baixinho. Porque já pensou, aquele mundo de mulher conversando alto. Conversava baixinho e sempre, sempre uma irmã nos rodeando. A gente não ficava sem uma freira a nós acompanhar um minuto. Desde levantar-se até a noite para dormir. Então essa freira ficava rodeando as mesas, olhando a maneira da gente comer, mastigar... aproveitava todos os momentos para educar a gente, sabe. Para ver se a gente estava comendo verduras. Olhava tudo, tudo, tudo sabe. Aí terminava o horário de almoço e a gente tinha meia hora para descanso. Nessa hora a gente podia conversar (Depoimento concedido em 2017). 
A essa rígida disciplina, que era utilizada para garantia da aprendizagem, juntava-se o silêncio. Juntos, silêncio e disciplina viabilizavam a formação dessas moças, que deveriam ser prendadas e com postura necessária aos moldes da época. $\mathrm{Na}$ Escola Normal, as alunas eram formadas primeira e principalmente para serem adeptas fiéis e praticantes contundentes do catolicismo. Por isso, a rotina vivenciada dentro da Escola Normal fomentava uma agenda antropológica pensada para que isso ocorresse. De acordo com a depoente "Nara":

Era uma obrigatoriedade ir à Missa todos os dias da semana, a oração antes e após qualquer atitude dum ser humano e a religiosidade em geral como sendo o principal para qualquer ser humano que entrava lá. Acho que eles, quando entrevistavam os pais, já perguntavam se eles estavam dispostos que seus filhos seriam verdadeiramente católicos, porque quando a gente passava do portão para dentro, a gente teria que ser verdadeiramente católico. Não tinha opção lá dentro não, eu não vou rezar, eu não quero rezar, não é hora de rezar, não tinha disso não. A gente agia normalmente como uma norma qualquer, seguir as normas, essas rotinas religiosas, isso também marcou muito (Depoimento concedido em 2017).

Percebe-se a partir desse depoimento que educar as moças era uma notória forma de difundir o catolicismo e, desse modo, as instituições religiosas dirigidas por freiras tinham um grande prestígio, pois as famílias sabiam da responsabilidade e do compromisso da Igreja com a moral católica.

As depoentes destacaram também o processo de ensino aprendizagem no colégio. Segundo elas, na época, privilegiava-se o ensino tradicional e, por isso, as alunas passavam na sala de estudos a maior parte do tempo. Em razão disso eram poucas as formas de lazer, incluindo visita à chácara das religiosas, além de passeios na rua, mas sempre acompanhadas de uma Irmã.

Com relação aos recursos didáticos, utilizavam-se quadro, giz e livros. Isso, segundo as alunas, era suficiente para a eficácia do processo ensino-aprendizagem, conforme pode ser visto no depoimento de "Clara", onde se lê: "A gente tinha os livros, era o mais básico para nossos estudos, mas elas explicavam a matéria e ficavam passando uma espécie de síntese da matéria no quadro, sabe. E a gente copiava. Então era um método tradicional, não tinha nada de novo” (Depoimento concedido em 2017). 
As avaliações eram diárias, pois incluíam não apenas as notas dos exames feitos, como também todo e qualquer ato do comportamento em seus mais finos detalhes. De acordo com a ex-aluna "Nara":

A gente tinha nota de matérias de conhecimentos adquiridos na sala e tinha nota do procedimento da gente, como você estendia uma cama, como escovava os dentes, como você tomava ao banho, como o seu sapato estava, as meias estavam bem puxadinhas abaixo do joelho (Depoimento concedido em 2017).

As provas finais ocorriam tanto em forma escrita quanto em forma oral e a matéria deveria estar na "ponta da língua", visto que, qualquer ponto poderia ser arguido. Nessa direção, a depoente "Clara" afirma que,

Tinha prova oral. Até de Música tinha prova oral. Latim então minha filha, eu estudei Latim. Tinha Latim oral e era a matéria que eu detestava, eu fui à prova oral de Latim declinar um verbo e fui "qua... que... qui... quo" e a lágrima escorrendo, chorando porque eu detestava Latim e tinha que falar tudo. Porque para escrever, eu escrevo melhor. Mas para falar, um trem decorado assim, então tinha prova oral sim e Hino Nacional de cor, minha filha. De cor, na aula de canto (Depoimento concedido em 2017).

Interessante observar que para além da agenda formativa católica e da preparação para o exercício do magistério, a Escola Normal, também, atendia ao propósito patriótico, evidentemente, no registro que alinhava civismo e patriotismo ao catolicismo.

No internato, além da formação intelectual, religiosa e profissional, também preparavam as moças para as prendas domésticas, conforme os ditames da família patriarcal. Dessa forma, as moças eram preparadas para a lida dentro dos lares, ou seja, o trabalho doméstico, tanto que, segundo a documentação escolar e o relato das depoentes, na grade curricular havia uma disciplina denominada Economia Doméstica.

Havia ainda aulas de socialização em que as alunas aprendiam a bordar, a colocar a mesa, a cuidar das roupas e aprendiam também etiqueta e puericultura. Somava-se a isso as aulas de música, em que aprendiam a tocar piano, bandolim e acordeom. Com relação ao ensino de línguas, as alunas tinham aulas de latim, francês e inglês. Isso tornava o colégio mais atrativo porque, além da formação intelectual e religiosa, proporcionava um refinamento das alunas que mormente era colocado em prática em suas vidas além internato, com especial atenção ao papel de futuras esposas e mães.

No que diz respeito às práticas culturais na escola, ressaltamos que as datas comemorativas eram muito importantes, pois eram uma forma das alunas 
representarem a escola em desfiles e serem admiradas pela população em geral, denotando, assim, a distinção daquelas que frequentavam o colégio, conferindo identidade à instituição educativa. Solenidades como aniversário da cidade, Dia de Nossa Senhora das Graças e o Sete de Setembro eram comemorados com esses desfiles. Nessa direção, a depoente "Clara" informou que "A escola tinha um calendário onde já estavam marcadas as datas comemorativas. E nós participávamos de todas, sendo as mais importantes as de 13 de maio [...] e 24 de maio, que era o dia do aniversário da cidade e as formaturas que eram lá mesmo" (Depoimento concedido, 2017). Na figura exposta a seguir é possível identificar uma aluna da escola em traje de gala destacando o brasão da instituição.

Figura 3 - Desfile em comemoração ao aniversário da cidade em 1959

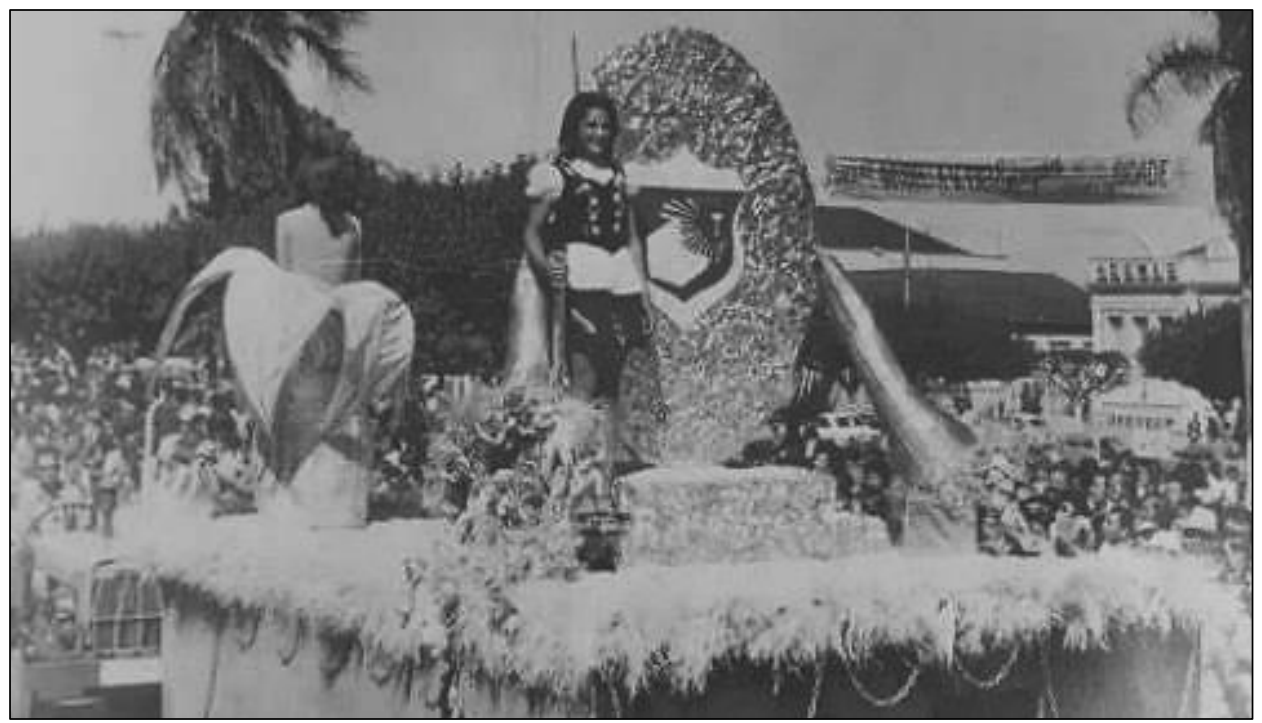

Fonte: Acervo Memorial do Milho de Patos de Minas, Minas Gerais, Brasil (1959).

No fragmento exposto a seguir, no qual se descrevem os trajes utilizados em ocasiões especiais, percebe-se as exigências de elegância e de postura que as alunas tinham que demonstrar quando participavam de eventos dessa natureza, a saber:

"Clara" - E comemorava com um desfile maravilhoso, a gente com um uniforme de gala, esse uniforme de gala era maravilhoso, sabe. Eu não sei nem o que foi feito do meu. Ele era plissado, azul pavão com blusa de seda branca, luva branca, boina branca, meia branca de seda até o joelho e sapatilha preta. (Depoimento concedido, 2017). 
"Lorena" - As datas comemorativas eram comemoradas com muito entusiasmo, tinha um uniforme de gala muito bonito, a expectativa do povo de Patos era ver o povo do colégio passar. Que era muito bonito. Nos desfiles de aniversário da cidade, Festa do Milho, essas datas assim que o colégio participava (depoimento concedido, 2017).

Figura 4 - Desfile na cidade com as alunas da Escola Normal em uniforme de gala

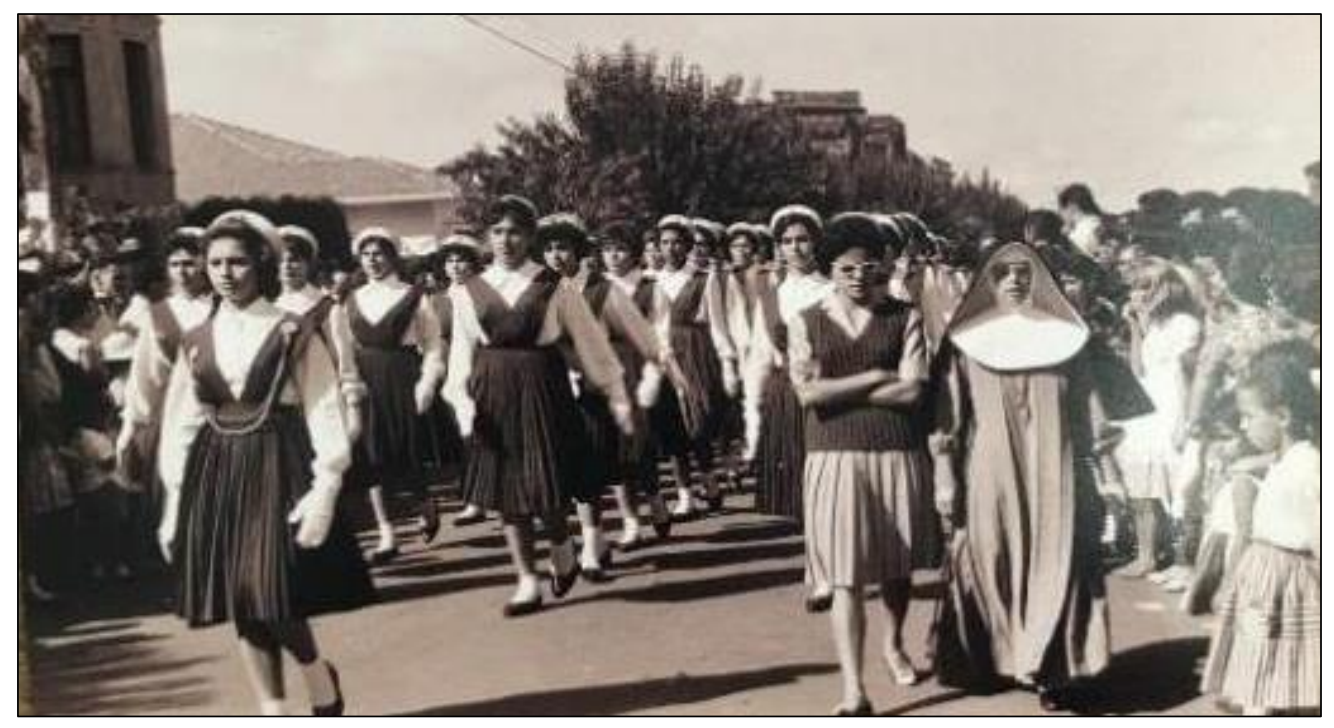

Fonte: acervo Memorial do Milho de Patos de Minas, Minas Gerais, Brasil.

Nas entrevistas foi possível perceber que disciplinas como Música e Canto simbolizavam uma efetivação das práticas cotidianas à Arte, à circunstância em que era valorosa a postura de moça bem-educada, bem-formada diante do público. Era importante o conhecimento de algum instrumento musical ou mesmo aptidão para recitar um poema ou atuar em alguma peça teatral. De acordo com "Margarida",

[...] Tinha teatro, sabe. Quando fizeram a parte grande do lado de cá. [...] Ali começaram a ser [...] o salão ainda é no mesmo lugar. O salão de festas. Um grandão que tem no meio. Do lado de cá. Aí começaram a fazer, foi melhorando... Festa do Milho. Eu fazia roupa pra minhas colegas. Tomei parte de tudo que tinha de Arte no Colégio. Fui crescendo e um dia um moço me perguntou se não era artista contratada do colégio. Eu e minha irmã que abrimos os desfiles da festa do milho no Colégio das Irmãs, depois eu deixei a abertura dos desfiles para fazer parte da Fanfarra, toquei todos os instrumentos (Depoimento concedido, 2017).

A formação cultural estava atrelada à instrução religiosa e moral, um elemento notório da proposta desse Colégio. Segundo Azzi (2008), Maria era o exemplo de mulher ideal, que deveria ser apreciada e modelo para as alunas. Era comum que a comunidade escolar participasse da Igreja local, sobretudo, durante o mês de maio, quando ocorria a tradicional Coroação de Nossa Senhora, nesse caso feita pelas alunas vestidas de anjo. 
Figura 5 - Solenidade de Formatura

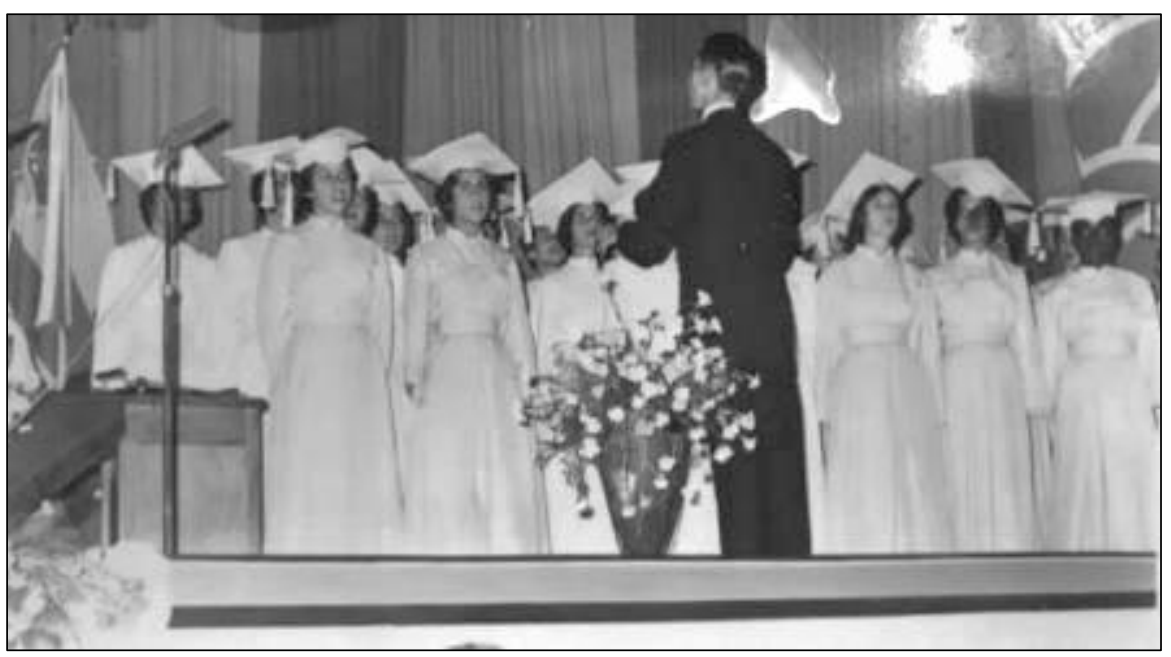

Fonte: acervo particular da depoente "Nara".

As festas de conclusão do ano escolar eram realizadas com toda a solenidade, com a presença das famílias das alunas e das autoridades locais, constituindo momento importante para a comunidade escolar, com atuação educativa das religiosas. Além disso, a imprensa faziase presente nesses eventos, dando ênfase a Escola Normal católica.

Depreende-se dos relatos das ex-alunas entrevistadas, no que diz respeito às práticas culturais e comparando-os às imagens, a importância do enfoque dado pela escola a conduta social e pública. Havia uma preocupação da escola em extrapolar seus muros, no sentido de apresentar a sociedade os resultados da educação oferecida pela referida Escola Normal. Isso reforçava sua identidade, embasada no modelo cristão e que presava pela boa educação, trazendo como princípios a civilidade, a disciplina, a moral e os bons costumes, valores essenciais para a formação da boa moça de família, reafirmando assim o compromisso das Irmãs Sacramentinas com a proposta de ensino, bem como com a postura da Igreja.

\section{Considerações finais}

Ao abordar a criação e a trajetória inicial da educação em Patos de Minas e do atual Colégio Nossa Senhora das Graças, percebe-se a importância que essa instituição teve para a cidade e para a região, tendo acumulado larga experiência em educação baseada em princípios católicos, pois completou 70 anos de fundação no ano de 2017. 
Nos primeiros cinco anos a Escola tinha caráter particular, de propriedade do Monsenhor Fleury Curado, mas com direção dos Sacramentinos, oferecendo o ensino ginasial misto, ou seja, para meninos e meninas. Em 1945 vieram as Irmãs Sacramentinas, oriundas da Manhumurim, Minas Gerais, para auxiliarem os padres no processo de gestão e de educação na escola. No entanto, a partir de 1948, elas assumem definitivamente a administração da escola implantando o sistema de internato para moças e, além do ginasial, também o Curso Normal para formação de professoras com duração até o final de 1959, quando a escola volta a oferecer o ensino misto e deixa de ser internato feminino.

Evidentemente que a atuação das Irmãs direcionou o processo de educação das crianças e das jovens e dos jovens que por ali passaram, ou seja, o espaço criado para instrução esteve sempre permeado pela doutrina, valores e princípios católicos.

Dessa forma, percebe-se a preparação das alunas e dos alunos para cumprirem os preceitos morais e religiosos predominantes na sociedade daquela época, em claro combate com outras possibilidades não católicas.

Ao se transformar em internato para moças, oferecendo os cursos ginasial e normal, a escola assume a formação feminina com dois objetivos explícitos. Primeiro, o de educar mulheres para serem boas esposas e mães exemplares. Segundo, para prepará-las para o exercício do magistério. Nesse duplo sentido formativo cumpria-se um só propósito, o de preparar mulheres capazes de reproduzir um código de valores e de princípios de uma determinada classe social sob o manto da Igreja Católica, com moças que estariam preparadas para educar seus filhos e os filhos de outras pessoas, educando, assim, os herdeiros da elite local no devido registro moral católico.

\section{Referências}

AZZI, Riolando. Igreja Católica na formação da sociedade brasileira. Aparecida: Santuário, 2008.

AZZI, Riolando. A Igreja no Brasil: da Apologética à Renovação Pastoral. A Atuação do Padre Júlio Maria e das Irmãs Sacramentinas (1912-1944). v. II. Belo Horizonte: Editora O Lutador, 1981. $408 \mathrm{p}$. 
BLOG Caminhos do Saber. Uma referência nacional em inclusão escolar! Blog Caminhos do Saber, 1 set. 2015. Disponível em: http:/ / caminhosdosaber.editorapositivo.com.br/categoria/colegionossa-senhora-das-gracas/page/2/. Acesso em: 14 set. 2019.

CLUBE NOTÍCIA. Alunos da Escola Professor Antonio Dias Maciel participam de projeto de incentivo ao empreendedorismo. Clube Notícia, [20-?]. Disponível em: https://www.clubenoticia.com.br/Noticia/index/5595. Acesso em: 11 set. 2019.

ESTATUTO DA ESCOLA NORMAL N. S. DAS GRAÇAS. Patos de Minas: [s.n.], 1952.

FERNANDES, Altamir. Colégio Estadual de Patos de Minas: memórias de sua criação. Patos de Minas: Edição do autor, 2017.

FOLHA DE PATOS. Patos de Minas, 1937. p. 2.

FOLHA DE PATOS. Patos de Minas, 30 jan. 1937. p. 3.

FONSECA, Geraldo. Dominios de pecuários e enxadachins: História de Patos de Minas. Belo Horizonte: Impressão Ingelbras, 1974. 303p.

LOMBAERDE, Júlio Maria de. O anjo das trevas: lampejo de doutrina, de ciência e de bomsenso. Rio de Janeiro: Vozes, 1950.

MELLO, Antônio Oliveira. Patos de Minas: capital do Milho. Edição da Academia Patense de Letras. Patos de Minas: Prefeitura Municipal de Patos de Minas, 1971.

MELlO, Antônio Oliveira. Patos de Minas: minha cidade. Edição da Academia Patense de Letras. Patos de Minas: Prefeitura Municipal de Patos de Minas, 1978.

MINAS GERAIS (Estado). Decreto n. 4065, de 23 de dezembro de 1913. Cria um Grupo Escolar na Cidade de Patos. Belo Horizonte, MG. Disponível em https://www.almg.gov.br/consulte/legislacao/completa/completa.html?tipo=DEC\&num $=4065 \&$ comp $=\& a n o=1913$. Acesso em: 13 jun. 2018 .

OLIVEIRA, Maria Guilhermina. Mosaico: 70 anos. Patos de Minas: [s.n.] 2015.

RESENDE, Silva Melina Brasil. O Curso Normal do Colégio Sagrado Coração de Jesus, Araguari/MG (1930-1947). 2006. Dissertação (Mestrado em Educação) — Universidade Federal de Uberlândia, UFU, Uberlândia, 2006.

VIEIRA, Elenice Maria de Sousa. Conhecendo o Colégio "Nossa Senhora das Graças", o tradicional Colégio das Irmãs. Patos de Minas: Argos. 2000.

RECEBIDO: $15 / 09 / 2019$

APROVADO: 25/10/2019
RECEIVED: 09/15/2019

APPROVED: $10 / 25 / 2019$
RECIBIDO: $15 / 09 / 2019$

APROBADO: 25/10/2019 